\title{
Environmental Characteristics in a Fish Farm with Copper Alloy Cage System in the Dardanelles
}

\author{
Sinan Uzundumlu' ${ }^{1}$ Yesim Buyukates ${ }^{1, *}$, Murat Yigit ${ }^{2}$, Musa Bulut ${ }^{2}$, \\ Rıdvan Kaan Gurses ${ }^{1}$ and Barbaros Celikkol ${ }^{3}$ \\ ${ }^{1}$ Canakkale Onsekiz Mart University, Faculty of Marine Science and Technology, \\ Department of Marine Science, Canakkale, Turkey \\ ${ }^{2}$ Canakkale Onsekiz Mart University, Faculty of Marine Science and Technology, \\ Departments of Aquaculture and Marine Technology, Canakkale, Turkey \\ ${ }^{3}$ University of New Hampshire, Department of Mechanical and Ocean Engineering, \\ New Hampshire, Durham, UNH, USA
}

\begin{abstract}
A B S T R A C T
This study was conducted in a copper alloy cage fish farm to observe the environmental properties of the marine system. Water quality parameters such as temperature, salinity, $\mathrm{pH}$ and dissolved oxygen, total suspended solids, chlorophyll-a and inorganic nutrients such as $\mathrm{NO}_{2}+\mathrm{NO}_{3}, \mathrm{NH}_{4}, \mathrm{PO} 4$ and $\mathrm{SiO}_{2}$ were observed between May 2014 and September 2014 in the study area. The observed results were compared with acceptable limits pronounced in international organizations such as EPA and FAO, and national organizations such as WPCR and RTMAF as well as the previous studies conducted in the region. According to the results, a decrease in dissolved oxygen and $\mathrm{pH}$ was observed at the farm while increases in inorganic nutrients except for ammonia were recorded. TSS values showed significant positive correlation with TP, indicating that TSS was supported by fecal pellets or unused fish feed in the cage system. MDS analysis results showed that TSS, chlorophyll-a and TP were similar throughout the sampling period. The study showed that copper alloy cage system did not have any negative impact on the marine system, compared with the limits provided by FAO, EPA, WPCR and RTMAF as well as with previously conducted studies in the region.
\end{abstract}
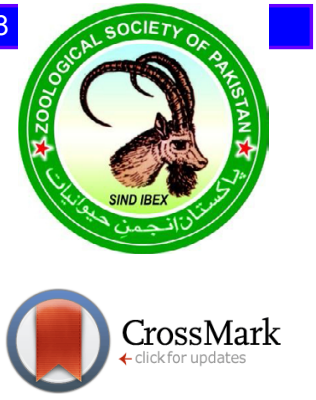

\section{INTRODUCTION}

$\mathrm{F}$ ish farming in cage systems is one of the most commonly used methods to fill the gap in Mediterranean aquaculture in recent years, with the rapid growth of seabream and seabass culture in off-shore facilities. While contributing to the economy through aquaculture, it is necessary to control the factors that may affect the ecological structure of the region. In fact, meeting the optimum water quality criteria required by fish in aquaculture is one of the most important factors in order to produce fish in the desired stock and reach the table size in a healthy way. However, the most important issue is the robustness of the mesh cages, regardless of the materials used. Therefore, preventive measures have to be taken against any risk of damages to the cage system due to wave, wind or any other reason and the system should be resistant to strong weather conditions. In order to cope with such negative factors and to provide optimum water

\footnotetext{
Corresponding author: ybuyukates@comu.edu.tr 0030-9923/2020/0006-2057 \$ 9.00/0

Copyright 2020 Zoological Society of Pakistan
}

quality criteria, different methods have been applied in cage farming in recent years. One of these methods is the use of copper alloy cages instead of traditional nylon nets known to cause organic material accumulation.

Earlier investigations on copper alloy mesh reported that these net materials with its stay-clean feature may provide a more favorable and non-stressful environment for fish. Furthermore, despite the higher initial investment costs, it was reported that copper alloy mesh could be economically beneficial in long term (Yigit et al., 2013; Grass et al., 2011; Berillis et al., 2017; Yigit et al., 2017). Besides, Tsukrov et al. (2011) reported that copper alloy nets are more resistant to high currents and storms. In an earlier study it was revealed that on an annual basis, high concentrations of $\mathrm{Cu}$ was release into the surrounding marine environment right after deployment of the system and throughout the first 3-4 months, but the release of $\mathrm{Cu}$ from the mesh seemed to be stabilized 9-10 months after installation (Kalantzi et al., 2016).

The expected yield in cage cultivation depends on many factors such as temperature, salinity, $\mathrm{pH}$ and dissolved oxygen concentrations as well as inorganic nutrients present in the environment, flow rate, feeding 
management and stock densities, or a combination of all these factors, which might be species-specific. Kalantzi et al. (2016) reported that bioaccumulation of $\mathrm{Cu}$ in fish mussel tissues followed the same trend with the $\mathrm{Cu}$ release progress from the mesh during the first 9 months of cage installation which decreased to similar values in mussel tissues from the nylon net cage after one year of cage deployment. Further, the authors reported that fish did not seem to be affected by the net type, and similarly the sediments also did not seem to be affected during the 1-year of experiment.

Table I. The acceptable limits for water quality variables and inorganic nutrients for aquaculture and fish farming in national and international organisations.

\begin{tabular}{lllll}
\hline Variable & RTMAF $^{1}$ & $\mathbf{W P C R}^{2}$ & $\mathbf{F A O}^{3}$ & $\mathbf{E P A}^{4}$ \\
\hline $\begin{array}{l}\text { Temperature } \\
\left({ }^{\circ} \mathrm{C}\right)\end{array}$ & $20-25$ & n.a. & $\begin{array}{l}\text { Species } \\
\text { specific }\end{array}$ & n.a. \\
Salinity (\%) & $5-44$ & n.a. & n.a. & n.a. \\
$\mathrm{pH}$ & $7.5-8.5$ & $6.0-9.0$ & $6.5-7.5$ & $5.5-8.5$ \\
$\mathrm{O}_{2}\left(\%-\mathrm{mg} \mathrm{L}^{-1}\right)$ & $4-8$ & $>90$ & $70-100$ & $30-60$ \\
$\mathrm{TSS}_{\left(\mathrm{mg} \mathrm{L}^{-1}\right)}$ & 2 & 30 & $25-100$ & n.a. \\
$\mathrm{NO}_{2}\left(\mathrm{mg} \mathrm{L}^{-1}\right)$ & 0.02 & n.a. & $0-0.5$ & $0.01-0.05$ \\
$\mathrm{NO}_{3}\left(\mathrm{mg} \mathrm{L}^{-1}\right)$ & $0.1-1$ & n.a. & $100-200$ & 50 \\
$\mathrm{NH}_{4}\left(\mathrm{mg} \mathrm{L}^{-1}\right)$ & $0.2-0.3$ & n.a. & $0-2.5$ & $0.04-1$ \\
$\mathrm{PO}_{4}\left(\mathrm{mg} \mathrm{L}^{-1}\right)$ & n.a & n.a. & $1-20$ & $0.5-0.7$ \\
$\mathrm{TP}_{\left(\mathrm{mg} \mathrm{L}^{-1}\right)}$ & n.a. & n.a. & n.a. & n.a \\
$\mathrm{SiO}_{2}\left(\mathrm{mg} \mathrm{L}^{-1}\right)$ & $2-5$ & n.a. & n.a. & n.a. \\
\hline
\end{tabular}

${ }^{1}$ Republic of Turkey Ministry of Agriculture and Forestry (Limit values for farming sea bream); ${ }^{2}$ Water Pollution Control Regulation of Republic of Turkey (Acceptable limits for aquaculture); ${ }^{3}$ Food and Agriculture Organization of the United Nations (Acceptable limits for aquaculture); ${ }^{4}$ Environmental Protection Agency (Acceptable limits for aquaculture).

Sea bream was grown in the experimental copper alloy mesh cage system, and the proposed water quality limit values proposed by various international organizations are given in Table I. Water quality characteristics in the area are widely studied and well established previously (Türkoğlu et al., 2004; Koçum, 2005; Aydın et al., 2010; Ateş et al., 2014), but the number of studies on the potential impact of cage farming with copper alloy mesh on water quality criteria is quite scarce with the only one report of Buyukates et al. (2017) in the Dardanelles. Therefore, the aim of this study was (1) to investigate the possible effects of copper alloy cages on marine systems, (2) to compare the water quality values obtained in the sea bream cage system with the marine water quality criteria of Environmental Protection Agency (EPA), the Food and Agriculture Organization of the United Nations (FAO),
Water Pollution Control Regulation of Republic of Turkey (WPCR) and Republic of Turkey Ministry of Agriculture and Forestry (RTMAF), and (3) to determine the similarity with the results obtained from the previous studies in the region if any.

\section{MATERIALS AND METHODS}

\section{Experimental location}

An offshore cage farm located in the northern part of the Aegean Sea was used in this study. The average depth of the farm location was $45 \mathrm{~m}$, with a gentle slope of sea bottom from 40 to $50 \mathrm{~m}$. The cage system was deployed $1.15 \mathrm{~km}$ (0.6 nautical miles) off the coast of a small town (Guzelyali) in the Strait of Canakkale (formerly known as Dardanelles) (Fig. 1), and the study site was far from terrestrial inputs. Operational period in the farm site lasted 150 days from May to September 2014. An antimicrobial wrought copper-zinc brass alloy with the ASTM designation of C44500 was produced into a cage net material, which contained $\mathrm{Cu}(70-73 \%)$, Zn (29.18$25.57 \%)$, Sn (0.80-1.20\%), P (0.02-0.10\%), Pb (0.07\%), and $\mathrm{Fe}(0.06 \%)$ according to the analyses presented by the German Copper Institute (https://www.kupferinstitut.de/ en/arbeitsmittel/kupferschluessel.html).

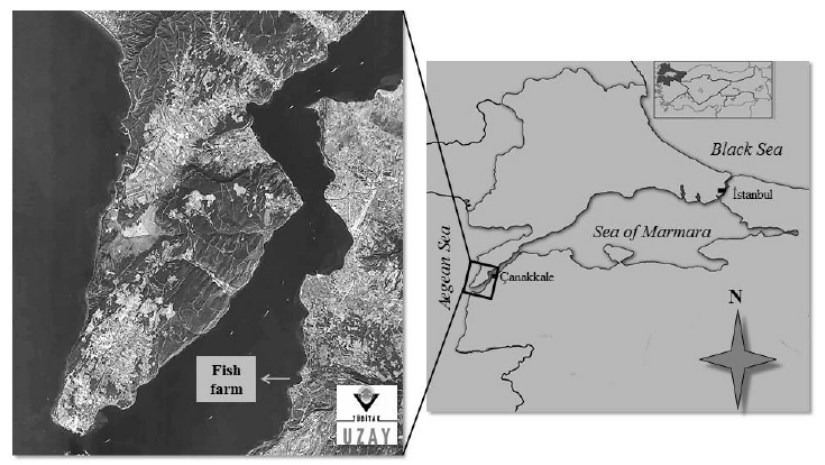

Fig. 1. Location of the fish farm with copper alloy cage system in Dardanelles

\section{Water quality analyses}

Seawater quality parameters were measured in the cage farm site over a 5 months period between 01 May and 30 September 2014 during the operational period. A multiprobe water quality analyzer (YSI 600 XL MPS) was used for the in situ measurement of water quality parameters such as temperature, salinity, dissolved oxygen (DO), and $\mathrm{pH}$. After sea water sampling using a $5 \mathrm{~L}$ water sampler for the nutrients, samples were filtered through $47 \mathrm{~mm}$ GF/F filters in the laboratory by gentle vacuum and then frozen for further analysis. Spectrophotometric analysis of nitrite+nitrate $\left(\mathrm{NO}_{2}+\mathrm{NO}_{3}\right)$, and ammonia $\left(\mathrm{NH}_{4}\right)$, soluble 
reactive phosphorus $\left(\mathrm{PO}_{4}\right)$, total phosphorus (TP) and silicate $\left(\mathrm{SiO}_{2}\right)$ were conducted according to Strickland and Parsons (1972). Gravimetric determinations of total suspended solids (TSS) were performed according to
Clesceri et al. (1998). Measurement of chlorophyll-a (chl-a) concentration was performed spectrophotmetrically after 90\% acetone extraction according to APHA (1995). All water quality parameters were determined in triplicate.
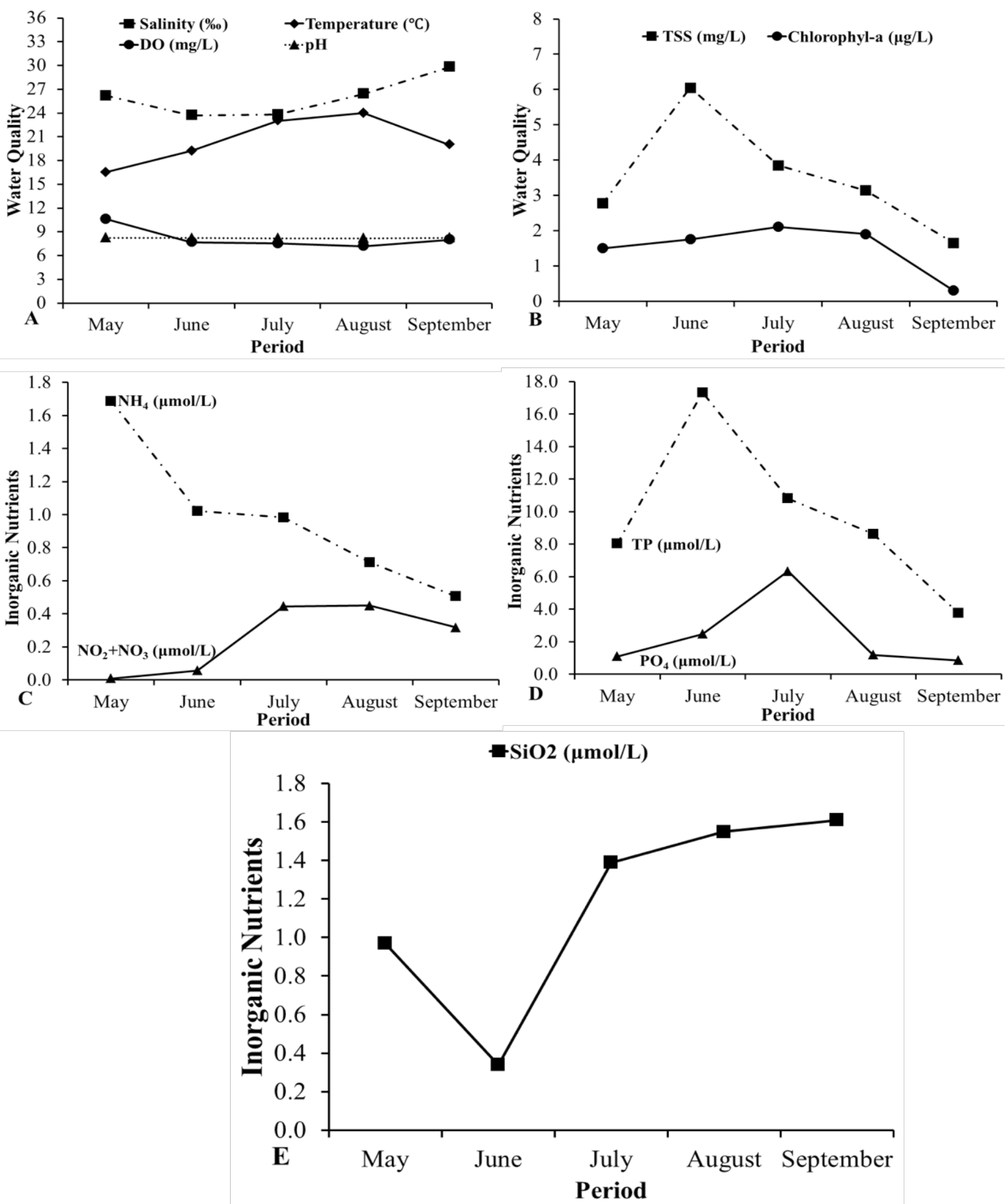

Fig. 2. Temporal variations of water quality parameters (A), TSS and Chlorophyll-a (B), NH4 and $\mathrm{NO}_{2}+\mathrm{NO}_{3}(\mathrm{C}), \mathrm{TP}_{\text {and }} \mathrm{PO}_{4}$ (D) and $\mathrm{SiO}_{2}$ (E) at the copper alloy mesh pen site between 01 May and 30 September 2014. 


\section{RESULTS}

In order to determine the possible effects of the cage system with copper alloy nettings on the water quality in the Dardanelles, the water quality criteria were monitored over a period of 5 months. The results were compared with values provided by international organizations such as EPA and FAO, as well as the limit values given by national organizations such as WPCR and RTMAF, and other studies previously conducted in the region.

The water quality parameters (temperature, salinity, dissolved oxygen and $\mathrm{pH}$ ) measured in $5 \mathrm{~m}$ depth from the surface at the farm site during the course of the five months period are presented in Figure 2A. Water temperature varied between 16.5 and $24.0^{\circ} \mathrm{C}$ and photoperiod followed the natural course during this period of the year (01 May - 30 September 2014). Salinity was recorded in the range between 23.7 and $29.8 \%$. A slight change was recorded for DO levels in seawater from 7.2 to $10.6 \mathrm{mg} \mathrm{L}^{-1}$, while the levels of $\mathrm{pH}$ were almost stable ranging between 8.2 and 8.25. The results for chl- $a$ and TSSs are shown in Figure 2B. As an indicator of primary production, the chl- $a$ ranged between 0.301 and $2.104 \mu \mathrm{g} \mathrm{L}^{-1}$, while the TSS ranged from 1.65 to $6.05 \mathrm{mg} \mathrm{L}^{-1}$ at $2 \mathrm{~m}$ depth from surface during the course of the 5 months period.

The findings for inorganic nutrient levels are given in Figure 2C-E. The values for $\mathrm{NH}_{4}$ and $\mathrm{NO}_{2}+\mathrm{NO}_{3}$ ranged from 0.51 to $1.69 \mu \mathrm{mol} \mathrm{L}^{-1}$, and 0.009 to $0.450 \mu \mathrm{mol} \mathrm{L}^{-1}$, respectively. The $\mathrm{PO}_{4}$ varried among the sampling periods with the lowest value in September and the highest in July, ranging from 0.86 to $6.34 \mu \mathrm{mol} \mathrm{L}^{-1}$. The TP values, ranging between 3.76 and $17.33 \mu \mathrm{mol} \mathrm{L}^{-1}$ also showed the lowest value in September and a peak in June. The $\mathrm{SiO}_{2}$ varied between 0.34 and $1.61 \mu \mathrm{mol} \mathrm{L}{ }^{-1}$ throughout the 5 months period.

\section{DISCUSSION}

The physicochemical values and inorganic nutrient concentrations obtained in the study were examined in 5 months period and no extreme deviations were detected. The lowest temperature value was recorded in May and the highest in August. The highest salinity values were measured in September showing the effects of the Aegean Sea current and the lowest salinity values were measured in June and July resembling the influence of the Black Sea current. $\mathrm{pH}$ values were found to correspond with the standard $\mathrm{pH}$ values of a marine environment (Kocataş, 1993). In addition, the temperature, salinity and $\mathrm{pH}$ values did not exceed the limit values presented by EPA, FAO, WPCR and RTMAF, and were found similar with previous studies in the region (Türkoğlu et al., 2004; Koçum, 2005; Odabaş1 and Buyukates, 2009; Aydın et al., 2010; Ateş et al., 2014). One of the most important factors in fish production is the concentration of dissolved oxygen (DO), dependent to temperature and salinity. It is known that a decrease in DO concentrations may cause a decrease in the resistance of fish to parasites and diseases, even if no lethal effects. Fish may refuse feeding under low DO concentrations $\left(<2 \mathrm{mg} \mathrm{L}^{-1}\right)$, which may adversely affect eating habits in return as well (Buttner et al., 1993). The DO values measured in the present study ranged from 7.2 to $10.6 \mathrm{mg} \mathrm{L}^{-1}$, where the highest value was observed in May when the water temperature was the lowest, while the lowest value was observed in August when the water temperature increased. The DO values varied in the range

Table II. Pearson correlations between water quality parameters and inorganic nutrients in the study area.

\begin{tabular}{|c|c|c|c|c|c|c|c|c|}
\hline Variable & Significant Level & $\mathrm{NO}_{2}+\mathrm{NO}_{3}$ & $\mathbf{N H}_{4}$ & $\mathrm{PO}_{4}$ & TP & $\mathrm{SiO}_{2}$ & TSS & Chl-a \\
\hline \multirow[t]{2}{*}{ Temperature } & $\mathrm{r}$ & $0.931^{*}$ & -0.663 & 0.414 & -0.022 & 0.555 & 0.005 & 0.37 \\
\hline & $p$ value & 0.022 & 0.222 & 0.489 & 0.972 & 0.331 & 0.993 & 0.54 \\
\hline \multirow[t]{2}{*}{ Salinity } & $\mathrm{r}$ & 0.145 & -0.421 & -0.667 & -0.877 & 0.611 & -0.857 & $-0.889^{*}$ \\
\hline & $p$ value & 0.816 & 0.481 & 0.21 & 0.051 & 0.274 & 0.063 & 0.043 \\
\hline \multirow[t]{2}{*}{$\mathrm{pH}$} & $\mathrm{r}$ & -0.73 & 0.332 & -0.773 & -0.336 & -0.225 & -0.349 & -0.687 \\
\hline & $p$ value & 0.161 & 0.585 & 0.125 & 0.58 & 0.717 & 0.564 & 0.20 \\
\hline \multirow[t]{2}{*}{ DO } & $\mathrm{r}$ & -0.717 & 0.83 & -343 & -0.232 & -0.234 & -0.282 & -0.181 \\
\hline & $p$ value & 0.172 & 0.082 & 0.572 & 0.707 & 0.704 & 0.645 & 0.77 \\
\hline \multirow[t]{2}{*}{ TSS } & $\mathrm{r}$ & -0.323 & 0.196 & 0.386 & $0.998 * *$ & -0.824 & 1 & 0.628 \\
\hline & $p$ value & 0.596 & 0.752 & 0.521 & 0 & 0.086 & & 0.256 \\
\hline \multirow[t]{2}{*}{ Chl- $a$} & $\mathrm{r}$ & 0.113 & 0.373 & 0.576 & 0.657 & -0.30 & 0.628 & 1 \\
\hline & $p$ value & 0.857 & 0.537 & 0.31 & 0.229 & 0.624 & 0.256 & \\
\hline
\end{tabular}


of FAO, WPCR, and RTMAF reports during the course of the study (Table I). In addition, the DO values in the present study were similar to earlier reports from the same region (Türkoğlu et al., 2004; Buyukates and Inanmaz, 2010; Ateș et al., 2014).

The amount of TSS has a significant effect on visibility, and can directly influence plankton growth, as an indirect effect on fish production. High levels of TSS concentrations are one of the important factors that should be controlled in fish farming as it may cause clogging of the gill filaments and off-flavor in fish (Buttner et al., 1993). The TSS values obtained in this study were significantly lower than the values given by FAO and did not exceed the limits provided by WPCR for marine systems which is $30 \mathrm{mg} \mathrm{L}^{-1}$. On the other hand, TSS values exceeded the limit value of $2 \mathrm{mg} \mathrm{L}^{-1}$ reported by RTMAF (Table I). The possible reason for this could be attributed to the over-feeding during that period. As a matter of fact, $\mathrm{NH}_{4}, \mathrm{PO}_{4}$ and TP concentrations were also higher in the summer season compared to the other months, which can be an indication of over feeding as well. In addition, no significant correlation was found between the TSS and the chl- $a$, which revealed that TSS was not controlled by primary production, but was significantly affected by TP concentration due to the significant correlation between these two variables (Table II). Thus, TSS was most probably under the influence of fecal waste or uneaten feed particles scattered from the cages. Additionally, the TSS and chl- $a$ values obtained in the present study also overlapped with the values in previous studies conducted in the region (Türkoğlu et al., 2004; Odabaşı and Buyukates, 2009; Buyukates and Inanmaz, 2010).

Uneaten fish feeds or fish feces released from the cage to the surrounding water environment might cause acidity, and therefore $\mathrm{pH}$ values are expected to be compatible with $\mathrm{NH}_{4}$ values (Tovar et al., 2000; Orçun and Sunlu, 2007). Excessive increase in $\mathrm{NH}_{4}$ values may cause high $\mathrm{pH}$ values and can be an important stress factor for fish. $\mathrm{NH}_{4}$ values obtained during the present study were quite low and the highest value was recorded in May. However, there was a positive correlation between the $\mathrm{NH}_{4}$ values and $\mathrm{pH}$, even though not significant (Table II). Moreover, the $\mathrm{NH}_{4}$ values recorded in the present study were similar to the values reported earlier in the same region (Odabaş1 and Buyukates, 2009; Buyukates and Inanmaz, 2010) and did not exceed the proposed limits for sea bream in the RTMAF reports and the water quality limits recommended by FAO and EPA. $\mathrm{SiO}_{2}$ values were under 30-40 $\mu \mathrm{g}$ $\mathrm{L}^{-1}$ which was the optimum growth concentration for diatioms in marine systems. The values coincided both with the values of previous studies conducted in the same marine area (Odabaşı and Büyükateş, 2009; Büyükateş and Inanmaz, 2010) and did not exceed the limit values recommended by RTMAF for sea bream production (Table I). It is known that $\mathrm{NO}_{2}+\mathrm{NO}_{3}$ values may increase as a result of high currents in the region besides domestic pollution (Türkoğlu et al., 2004). As a result of the study, $\mathrm{NO}_{2}+\mathrm{NO}_{3}$ values showed significant positive correlation with temperature (Table II). An increase in $\mathrm{NO}_{2}+\mathrm{NO}_{3}$ values was observed with the increase in temperature, but this increase was not at the level of the limit values of FAO, EPA, WPCR and RTMAF. On the other hand, $\mathrm{NO}_{2}+\mathrm{NO}_{3}$ values were similar to those found in previous studies (Türkoğlu et al., 2004; Odabaşı and Buyukates, 2009; Buyukates and Inanmaz, 2010). Fazio et al. (2013) showed the influence of water quality on blood parameters in cultured fish. The evaluation of blood parameters representing an important tool for aquaculture systems and it can reveal important information on fish physiology and health (Fazio, 2019). MDS analysis was performed in order to find the similarity of water quality values and variations of inorganic nutrients during the study and it was observed that 4 different groups were formed as a result of the analysis. According to the analysis, $1^{\text {st }}$ group consisted of salinity, $\mathrm{SiO}_{2}$ and $\mathrm{NO}_{2}+\mathrm{NO}_{3}, 2^{\text {nd }}$ group consisted of temperature and $\mathrm{PO}_{4}, 3^{\text {rd }}$ group consisted of $\mathrm{pH}$ and $\mathrm{NH}_{4}$ and DO, and the $4^{\text {th }}$ group consisted of TSS, chl- $a$ and TP (Fig. 3). This showed that the values of the variables in the same group were similar in their variations within the study period.

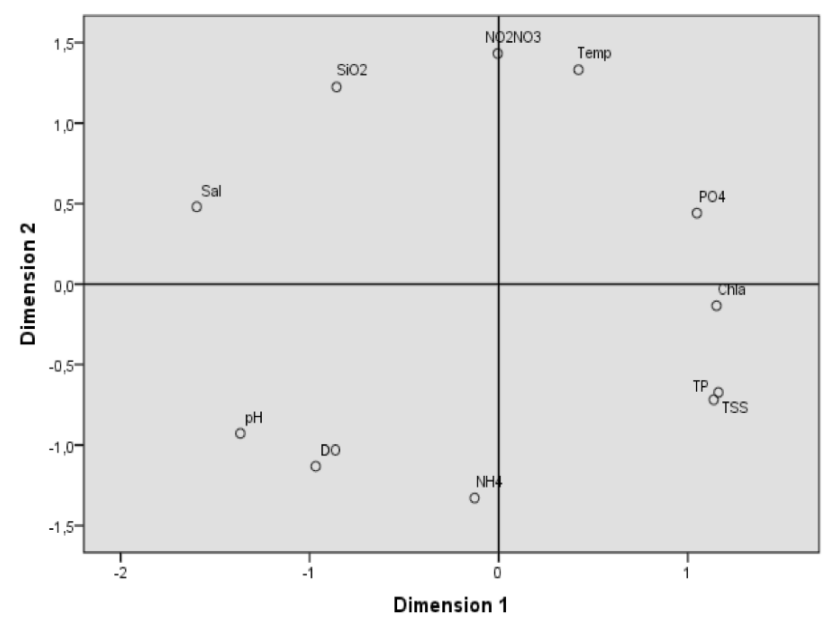

Fig. 3. MDS plot of water quality variables and inorganic nutrients in study area

\section{CONCLUSIONS}

As a result of the study, it was determined that copper alloy cages did not adversely affect the water quality in 
the studied marine ecosystem. Considering the physical problems and organic matter accumulation on traditional nylon mesh, potentially causing stressed environment for fish due to nuisance of net changes, and therefore reducing fish growth performance, the use of copper alloy mesh in marine aquaculture might be beneficial for environmentfriendly farm operations and sustainable marine aquaculture activities with increased fish welfare or health conditions and reduced operational costs in long run.

\section{ACKNOWLEDGEMENTS}

The International Copper Association (ICA), New York - USA is acknowledged for the financial support (project fund: ICA-TEK Project No: 1049-20, Canakkale). We would like to thank Hal Stillman (Global Initiative Leader for Technology Transfer, International Copper Association-USA) and Langley Gace (President of InnovaSea Systems, Inc. USA) for technical advices and support.

\section{Statement of conflict of interest}

The authors declare that there is no conflict of interests regarding the publication of this article.

\section{REFERENCES}

APHA, 1995. American Public Health Association (APHA), American Water Works Association, Water Environment Federation, 1995. Standard methods for the examination of water and wastewater. Washington DC, USA.

Ates, A.S., Katağan, T., Sezgin, M., Özdilek, H.G., Berber, S. and Bulut, M., 2014. The effects of some domestic pollutants on the cumacean (Crustacea) community structure at the coastal waters of the Dardanelles, Turkey. Arthropods, 3: 27.

Aydin, A., Kahraman, T. and Aydin, H., 2010. The microbiological and physico-chemical parameters with trace metal pollution of coastal bathing water in Dardanelles and Thracian Sea. J. Anim. Vet. Advan., 9: 1077-1082. https://doi.org/10.3923/ javaa.2010.1077.1082

Berillis, P., Mente, E. and Kormas., K.A., 2017. The use of copper alloy in aquaculture fish net pens: mechanical, economic and environmental advantage. J. Fish. Sci., 11:001-003. https://doi. org/10.21767/1307-234X.1000134

Buttner, J.K., Soderberg, R.W. and Terlizzi, D.E., 1993. An introduction to water chemistry in freshwater aquaculture. Northeastern Regional Aquaculture Center (NRAC). University of Massachusetts,
Dartmouth, USA. pp. 170-1993.

Buyukates, Y. and İnanmaz, Ö.E., 2010. The Annual Mesozooplankton Dynamics and influence of environmental parameters in an urbanized harbor (Kepez Harbor-Dardanelles Strait, Turkey). Ekoloji, 19: 60-68. https://doi.org/10.5053/ekoloji.2010.749

Buyukates, Y., Celikkol, B., Yigit, M., Decew, J. and Bulut, M., 2017. Environmental monitoring around an offshore fish farm with copper alloy mesh pens in the Northern Aegean Sea. Am. J. Environ. Protec., 6: 50-61. https://doi.org/10.11648/j. ajep.20170602.13

Clesceri, L.S., Greenberg, A.E. and Eaton, A.E., 1998. Standard methods for the examination of water and wastewater. Method 2540 B. (Total Solids). Method 2540 C. (Total Dissolved Solids) and Method 2540 D. (Total Suspended Solids). $20^{\text {th }}$ edn. Washington DC, USA.

Fazio, F., Faggio, C., Marafioti, S., Torre, A., Sanfilippo, M. and Piccione, G., 2013. Effect of water quality on haematological and biochemical parameters of Gobius niger caught in Faro lake (Sicily). Iranian J. Fish. Sci., 12: 219- 231.

Fazio, F., 2019. Fish hematology analysis as an important tool of aquaculture: a review. Aquaculture, 500: 237-242. https://doi.org/10.1016/j. aquaculture.2018.10.030

Grass, G., Rensing, C. and Solioz, M., 2011. Metallic copper as an antimicrobial surface. Appl. environ. Microbiol., 77: 1541-1547. https://doi.org/10.1128/ AEM.02766-10

Kalantzi, I., Zeri, C., Catsiki, V.A., Tsangaris, C., Strogyloudi, E., Kaberi, H., Vergopoulos, N. and Tsapakis, M., 2016. Assessment of the use of copper alloy aquaculture nets: Potential impacts on the marine environment and on the farmed fish. Aquaculture, 46: 209-222. https://doi.org/10.1016/j. aquaculture.2016.09.016

Kocataş, A., 1993. Oseanoloji. Ege Üniversitesi Kitaplar Serisi. Bornova. İzmir.

Koçum, E., 2005. Çanakkale Boğazı'nda klorofil-a ve çözünmüş mineral besin elementi miktarlarının analizi. Ekoloji, 14: 1-6.

Odabaşı, S. and Buyukates, Y., 2009. Daily variation of chlorophyll- $a$, environmental parameters and nutrients: Sarıçay creek as an exemplary (Çanakkale, Turkey). Ekoloji, 19: 76-85. https:// doi.org/10.5053/ekoloji.2009.7310

Orçun, E. and Sunlu U., 2007. Sığacık (Seferihisar - İzmir) Bölgesi Ağ Kafeslerde Yapılan Balık Yetiștiriciliğinin Sucul Ortama Olan Etkilerinin Araştırılması. Ege J. Fish aquat. Sci., 24: 01-09. 
Strickland, J.D.H. and Parsons, T.R., 1972. A practical handbook of seawater analysis. Fisheries Research Board of Canada. 2nd ed.

Tovar, A., Moreno, C., Mánuel-Vez, M.P. and GarcíaVargas, M., 2000. Environmental impacts of intensive aquaculture in marine waters. Water Res., 34: 334-342. https://doi.org/10.1016/S00431354(99)00102-5

Tsukrov, I., Drach, A., DeCew, J., Swift, M.R. and Celikkol, B., 2011. Characterization of geometry and normal drag coefficients of copper nets. Ocean Eng., 38: 1979- 1988. https://doi.org/10.1016/j. oceaneng.2011.09.019

Türkoğlu, M., Yenici, E., İşmen, A. and Kaya, S., 2004. Çanakkale Boğazı' nda Nütrient ve Klorofil-a
Düzeylerinde Meydana Gelen Aylık Değişimler. Ege J. Fish aquat. Sci., 21: 93-98.

Yigit, M., Celikkol, B., Gace, L., DeCew, J., Hisar, O., Bulut, M., Yildiz, H., Ozalp, B., Kaya, H., Yilmaz, S. and Irkin, L.C., 2013. Present state and future expectations of Mediterranean aquaculture: environmental concern and benefits of copper alloy nettings for a sustainable high value aquaculture industry. WAS-Asian pacific, High value aquaculture finfish symposium. Kagoshima University-Japan, 15-18 October 2013.

Yigit, Ü., Ergün, S., Bulut, M., Celikkol, B. and Yigit, M., 2017. Bioeconomic efficiency of copper alloy mesh technology in offshore cage systems for sustainable aquaculture. Int. J. Geo-Marine Sci., 46: 2017-2024. 